\title{
The Determinants of Sustainable Land Management Adoption under Risks in Upland Area of Vietnam
}

\author{
Dr. Ho Ngoc Cuong ${ }^{l}$; Prof. Dr. Nguyen Van Song ${ }^{1}$; \\ Dr. Vu Ngoc Huyen ${ }^{1}$; Dr. Roberto F. Rañola, Jr. ${ }^{2}$ \\ ${ }^{1}$ Faculty of Economics and Rural development (FERD) \\ Vietnam National University of Agriculture (VNUA), Trauquy, Gialam, Hanoi, Vietnam \\ ${ }^{2}$ College of Economics and Management, University of the Philippines Los Banos, The Philippines
}

\begin{abstract}
This study investigates how the determinants including risk preference affect farmers' decision to adopt SLM practices in upland areas of Vietnam. Empirical data collected through in-depth interviews with 200 farmers in Na Ri district, Bac Kan province were used. The factors affecting SLM adoption of farmers in Na Ri district were examined by the 2SLS or IV-Probit model. The estimated 2SLS regression indicated that there is a set of factors affecting SLM adoption, namely, relative risk aversion, farming experience, farm size, knowledge of SLM, membership in farmers' organization, number of labors, and slope of farm land. Specifically, relative risk aversion had a negative effect on SLM practices adoption. The farmers who are less risk averse are more likely to adopt more SLM practices. This implies that reducing farmer' risk exposure could promote SLM practices. This result is also helpful for policymakers to understand farmers' behaviors and promote the diffusion of SLM practices across regions on a large scale.
\end{abstract}

Keywords: Sustainable land management, adoption, risk, upland, Vietnam

\section{Introduction}

Land is a vital resource for producing food (Babalola and Olayemi, 2013; Agboola et al., 2015) and other ecosystem goods and services including conserving biodiversity, regulating hydrological regimes, cycling soil nutrients, and storing carbon, among others (Nachtergaele, 2010 cited by Saguye, 2017a; Kasaye, 2017; Samandari, 2017). However, Most of the upland areas in Vietnam is degraded; $50 \%$ low in N, $87 \%$ low in P, $80 \%$ low in K, $72 \%$ in Ca, and $48 \%$ low in Mg (Tien, 2015). A study of Sutton et al. (2016), showed that due to land degradation, the value of the total ecosystem services of the upland areas of Vietnam has been reduced from $162,603,792,051$ US\$/year to $132,965,385,577$ US\$/year.

SLM practices are thus a major tool for sustaining livelihoods and agricultural production at the individual farm level and ensuring food security for the coming generations. While substantial efforts have been made since the mid-1990s to promote sustainable land management as soil conservation technologies in Vietnam (van der Poel, 1996; UNDP, 2000 cited by Keil and Nielsen, 2012), adoption rates have remained low (Wezel et al., 2002; Saint-Macary et al., 2010). The low rate of adoption of these management practices remains a key bottle neck for making real progress in combating land degradation (Nkonya et al., 2011).

Some studies on the economics of sustainable land management have suggested incentives for farmers to adopt sustainable land management practices based on the analysis of their household characteristics as well as the features and attributes of their farm operations 
(Semgalawe, 1998; Namboth, 2015; Menozzi et al., 2015; Saguye, 2017a; Zeweld et al., 2018; Meijer et al., 2014; Vo et al., 2018; Wang et al., 2018). According to Tenge et al. (2004) and Bravo-Ureta et al. (2006), the analyses to determine the factors affecting land degradation often focus exclusively on characteristics at household level, including the socio-economic characteristics of the farmers (age, gender, level of education, etc.), characteristics of the plot and the natural conditions (farm size, plot size, slope), farm management practices, and institutional aspects (support programs, access to credits, etc.) to explain land degradation (Tenge et al., 2004; Bravo-Ureta et al., 2006 cited by Nkonya et al., 2016). Rarely, however, has the influence of risk aversion for adoption of sustainable land management practices been addressed.

Unfortunately, measures of risk preferences in low income countries are fairly rare (Bezabih and Sarr, 2013) and there is lack of research in Vietnam to determine the factors affecting SLM adoption of the farmers and the effect of risk preferences of upland farmers on SLM adoption as well as the willingness of upland farmers to adopt sustainable land management. A good understanding of the factors affecting farmers' risk preferences and their decisions on SLM practices, however, would be important for formulating informed policy making.

\section{Literature review}

Risk in agriculture. Agriculture is often carried out in the field and always entails the management of inherently variable living plants and animals so that it is especially exposed to risk. Sources of risk in the farming can be classified in many ways such as production risk, market risk, financial risk, technological risk, accident risk, institutional risk, and human risk.

Risk preferences. Risk preference refers to the attitude people hold towards risks (Dadzie and Acquah, 2012). In terms of farmers' attitudes toward risk, farmers differ in the degree to which they accept risk. Some farmers are willing to accept more risk than others. Attitudes to risk are often related to the financial ability of the farmer to accept a small gain or loss. Farmers' attitudes may be classified as risk-averse, those who try to avoid taking risks; risktakers, those who are open to more risky business options; and risk-neutral farmers, those who lie between the risk-averse and risk-taking position.

Risk preferences and farming decision. Some recent studies form Wang et al. (2016), Mao et al. (2018), Saguye (2017a,b,c), Liu et al. (2018) contributed a stronger conclusion about the relationship between risk preferences and farming decision. According to Wang et al. (2016), farmers with a higher risk preference are more likely to adopt eco-friendly agricultural practices. Mao et al. (2018) also concluded that there is existing relationship between farmers' risk preferences and technology adoption decision of broiler farmers in China. Saguye (2017a,b) also pointed out that adoption of agricultural technologies is affected by various factors including risk aversion behavior. This finding was consistent with the study of Liu et al. (2018). They stated that individual characteristics of farmers (including age, experience, education, risk preference, heritage, "lifestyle", and environmental consciousness) influence their awareness of and interest in Best Management Practices (BMPs), and ultimately their perceptions and decisions

Sustainable land management practices. The concept of sustainable land management has been discussed by numerous scholars. In 1991, Dumanski indicated that sustainable land management (SLM) is a package of technologies applied at all levels of land use, which 
individually or in aggregate contribute to sustainable agriculture (cited by Maglinao, 2000). SLM aims at maximizing the efficient use of inputs in relation to the amount and quality of the outputs, while incorporating long-term environmental and social concerns associated with the outputs. As discussed by Babalola and Olayemi (2013); Zeweld et al. (2018); Saguye (2017a,2017c); Teklewold and Köhlin (2011); Ogada et al. (2010), the factors influencing SLM practices adoption decision are experience, age, gender, education, farmer health, income, household size, farm size, land tenure, social network, distance to market, dependency-ratio, number of crops grown, access to extension, technical training, knowledge of SLM, attitude, weather variables, value of livestock, slope of plot, and off farm activities.

\section{Research Methodology}

$\mathrm{Na}$ Ri district where this study was conducted belongs to the Bac Kan province which is one of the most degraded upland areas of Vietnam. This is a typical district of the uplands of Vietnam. In Na Ri district, farmers face multiple risk factors related to the biological nature of production, small market and farm diseases. In addition, the constraints include the high ecological fragility of the sloping land, farmers' limited access to resources for agricultural production, lack of alternative forms of employment, education, and technology, and weak markets for both agricultural inputs and outputs.

The 200 farmer- respondents were invited for interview. All of them are main decision makers in their households in $\mathrm{Na}$ Ri district randomly selected from 9 villages of 2 communes (table 1).

Table 1. Sample- respondents in Na Ri district, Bac Kan, Vietnam, 2019

\begin{tabular}{lrrr}
\hline \hline Na Ri & \multicolumn{1}{c}{ Male } & \multicolumn{1}{c}{ Female } & \multicolumn{2}{c}{ Total } \\
\hline Lamson commune & 81 & 24 & 105 \\
Cule commune & 54 & 41 & 95 \\
\hline Total & 135 & 65 & 200 \\
\hline \hline
\end{tabular}

The modified multiple price list method of Holt and Laury (2002) was used to elicit the farmers' risk preferences. The subjects were provided with documentation detailing instructions and outlining the various lottery asks. They were also encouraged to ask questions. Table 2 replicates the eight tasks presented to subjects. For each binary-choice lottery task, subjects picked either Lottery A or Lottery B. In this study, fixed probabilities of 100\% and 50\% were used in the experiment. In the first task, subjects have a 100\% chance of receiving Vnd80,000 under Lottery A; under Lottery B they have a 50\% chance of receiving Vnd80,000, and a 50\% chance of receiving nothing. The payoff associated with Lottery A declines systematically throughout the eight tasks, while the payoff for Lottery B remains unchanged. 
Table 2. The experimental game tasks to elicit risk preferences

\begin{tabular}{|c|c|c|c|c|c|c|}
\hline Task & Lottery A & Lottery B & $\underset{\mathbf{A}}{\text { EV_Lot }}$ & $\underset{\bar{B}}{\text { EV_Lot }}$ & CRRA & $\begin{array}{c}\text { Risk } \\
\text { classification }\end{array}$ \\
\hline $0-1$ & $\begin{array}{c}\text { Vnd } \\
80,000\end{array}$ & $\begin{array}{l}0.5 \text { of Vnd } 80,000 \\
\text { and } 0.5 \text { of Vnd } 0\end{array}$ & $\begin{array}{l}\text { Vnd } \\
80,000\end{array}$ & $\begin{array}{l}\text { Vnd } \\
40,000\end{array}$ & $\mathrm{r}<-4.19$ & $\begin{array}{l}\text { Highly } \\
\text { risk-loving }\end{array}$ \\
\hline 2 & $\begin{array}{l}\text { Vnd } \\
70,000\end{array}$ & $\begin{array}{l}0.5 \text { of Vnd } 80,000 \\
\text { and } 0.5 \text { of Vnd } 0\end{array}$ & $\begin{array}{c}\text { Vnd } \\
70,000\end{array}$ & $\begin{array}{l}\text { Vnd } \\
40,000\end{array}$ & $\begin{array}{c}-4.19<\mathrm{r} \\
<-1.40\end{array}$ & $\begin{array}{l}\text { Very } \\
\text { risk-loving }\end{array}$ \\
\hline 3 & $\begin{array}{l}\text { Vnd } \\
60,000\end{array}$ & $\begin{array}{l}0.5 \text { of } \mathrm{Vnd} 80,000 \\
\text { and } 0.5 \text { of Vnd } 0\end{array}$ & $\begin{array}{l}\text { Vnd } \\
60,000\end{array}$ & $\begin{array}{l}\text { Vnd } \\
40,000\end{array}$ & $-1.40<\mathrm{r}<-0.47$ & Risk-loving \\
\hline 4 & $\begin{array}{l}\text { Vnd } \\
50,000\end{array}$ & $\begin{array}{l}0.5 \text { of Vnd } 80,000 \\
\text { and } 0.5 \text { of Vnd } 0\end{array}$ & $\begin{array}{l}\text { Vnd } \\
50,000\end{array}$ & $\begin{array}{l}\text { Vnd } \\
40,000\end{array}$ & $-0.47<\mathrm{r}<0$ & $\begin{array}{l}\text { Slightly risk- } \\
\text { loving }\end{array}$ \\
\hline 5 & $\begin{array}{c}\text { Vnd } \\
40,000\end{array}$ & $\begin{array}{l}0.5 \text { of Vnd } 80,000 \\
\text { and } 0.5 \text { of Vnd } 0\end{array}$ & $\begin{array}{l}\text { Vnd } \\
40,000\end{array}$ & $\begin{array}{l}\text { Vnd } \\
40,000\end{array}$ & $0<\mathrm{r}<0.29$ & Risk neutral \\
\hline 6 & $\begin{array}{c}\text { Vnd } \\
30,000\end{array}$ & $\begin{array}{l}0.5 \text { of Vnd } 80,000 \\
\text { and } 0.5 \text { of Vnd } 0\end{array}$ & $\begin{array}{c}\text { Vnd } \\
30,000\end{array}$ & $\begin{array}{l}\text { Vnd } \\
40,000\end{array}$ & $0.29<\mathrm{r}<0.5$ & $\begin{array}{l}\text { Slightly risk } \\
\text { averse }\end{array}$ \\
\hline 7 & $\begin{array}{c}\text { Vnd } \\
20,000\end{array}$ & $\begin{array}{l}0.5 \text { of Vnd } 80,000 \\
\text { and } 0.5 \text { of Vnd } 0\end{array}$ & $\begin{array}{c}\text { Vnd } \\
20,000\end{array}$ & $\begin{array}{l}\text { Vnd } \\
40,000\end{array}$ & $0.50<r<0.67$ & Risk averse \\
\hline 8 & $\begin{array}{l}\text { Vnd } \\
10,000\end{array}$ & $\begin{array}{l}0.5 \text { of } V \text { nd } 80,000 \\
\text { and } 0.5 \text { of Vnd } 0\end{array}$ & $\begin{array}{l}\text { Vnd } \\
10,000\end{array}$ & $\begin{array}{c}\text { Vnd } \\
40,000\end{array}$ & $0.67<r$ & $\begin{array}{l}\text { Highly risk } \\
\text { averse }\end{array}$ \\
\hline
\end{tabular}

The number of safe decision choices (NSCs) from the MPL game was converted into risk preferences. Number of safe choice was the number of safe lottery the respondent chose in the game (Lottery A) before he/she switched to the risky lottery (Lottery B). For example, the subject who chose (1A, 2A, 3A) from 8 tasks of MPL has NSCs of 3 because three of these choices are the safer one in the lotteries A and B. The NSCs range from 0 to 8. A lower value of NSCs indicates a greater willingness to bear risk. NSCs were used as measure of each subject's risk preferences by using a CRRA utility function defined over the lottery prize. The CRRA function is of the form $\mathrm{u}(\mathrm{w})=\frac{w^{1-\mathrm{r}}}{1-\mathrm{r}}$ where $w$ is the lottery prize and $\mathrm{r}$ is the latent risk coefficient

\subsection{Determining the factors affecting the SLM practices adoption decision under risk}

Adoption of SLM technologies/practices in this study referred to the use of one or more SLM technologies. The adoption of SLM technology/practices at the farm level was measured as a binary dummy variable. An adopter was defined as a farmer using at least one SLM practice (Adopter $=1$; Non Adopter $=0$ ). To determine the physical, institutional and other factors including risk preferences affecting the SLM practices adoption decision, the instrumental variable (IV) Probit estimation was used following the specification. Risk preference was estimated in the first-stage. The dependent and explanatory variables are shown in the Table 3. 


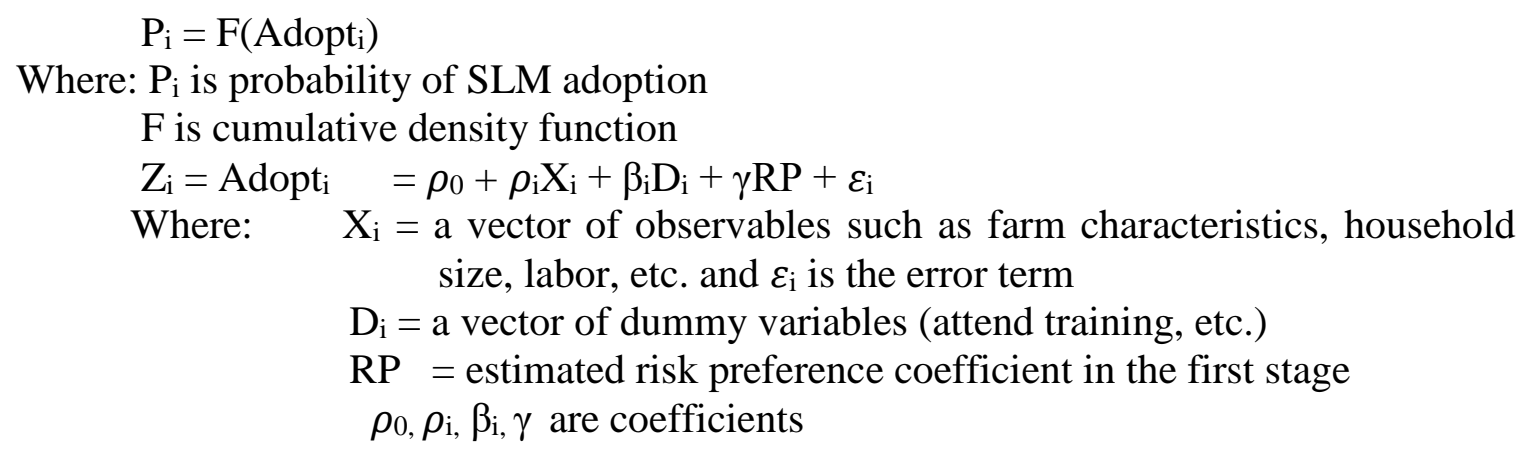

Table 3. Definitions of explanatory variables used in the IV-Probit model

\begin{tabular}{|c|c|}
\hline Variable & Description \\
\hline Adopt & $\begin{array}{l}\text { Farmers using at least one SLM practice } \\
(\text { Adopter }=1 ; \text { Non Adopter }=0 \text { ) }\end{array}$ \\
\hline $\begin{array}{l}\text { Relative risk coefficient } \\
\text { (RP) } \\
\text { exper }\end{array}$ & $\begin{array}{l}\text { Relative risk aversion coefficient was estimated from first- } \\
\text { stage in risk preferences regression model } \\
\text { Experience of farmer in farming (years) }\end{array}$ \\
\hline Annual_fsize & Total annual crop area $\left(\mathrm{m}^{2}\right)$ \\
\hline Forest\&Pre_fsize & Total forest and perennial area $\left(\mathrm{m}^{2}\right)$ \\
\hline kofslm & $\begin{array}{l}\text { Knowledge of farmers about SLM practices } \\
\text { (the number of SLM practices perceived by respondent) }\end{array}$ \\
\hline training & $\begin{array}{l}\text { Attend training (if farmers attend any training }=1,0 \\
\text { otherwise) }\end{array}$ \\
\hline member & Membership in farmers' organization $=1,0$ otherwise \\
\hline credit & $\begin{array}{l}\text { Access credit } \\
\text { (if farmers borrows money from bank or any external } \\
\text { source of fund }=1,0 \text { otherwise) }\end{array}$ \\
\hline hh_size & Number of people in the household \\
\hline labor & Number of labor in the household \\
\hline slope & $\begin{array}{l}\text { Slope of farm land } \\
\text { Very steep }=1 \text {, Steep }=2 \text {, Gentle slope }=3 \text {, Flat }=4 \text {, } \\
\text { Others }=5\end{array}$ \\
\hline
\end{tabular}

\section{Results and Discussion}

\subsection{The description of respondents}

The survey was conducted with 200 respondents in Na Ri district to study the situation of land degradation at the household level. This results show the current situation of sustainable land management application as well as identity the solution used to improve land condition. Table 4 shows the general characteristics of selected households in Na Ri district. There were 
200 respondents interviewed, of which 65 are female and 135 are male. All the respondents are the decision makers in their households. The average age is 46.5 with average school years around 8.5. The average household size is 4.3 persons/household and 2.7 working persons on average. Almost all of them have long experience in farming (22.7 years on average). Total average annual crop size is about 3,776 square meters, while total forest and perennial crop area is 5,208 square meters on average. The total average income per household per year is 47.2 million dong (US\$2,052), of which 39.1 million dong (US\$ 1,700) is farm income per year equivalent to $82.83 \%$ total income.

Table 4. Description of farm-households, 200 respondents, Na Ri district, Bac Kan, 2019

\begin{tabular}{llrr}
\hline Item & Unit & Mean & Std.Dev \\
\hline Respondents & Person & 200 & - \\
$\quad$ Male & Person & 135 & - \\
$\quad$ Female & Person & 65 & - \\
Age & Year & 46.5 & 11.5 \\
Education & School year & 8.5 & 2.7 \\
Household size (number of persons) & Person & 4.3 & 1.2 \\
Labor & Person & 2.7 & 0.9 \\
Experience & Year & 22.7 & 11.5 \\
Total annual crops area & $\mathrm{m}^{2}$ & 3,776 & 1,620 \\
Total forest and perennial crop area & $\mathrm{m}^{2}$ & 5,208 & 4,804 \\
Total income & Million dong & 47.2 & 25.8 \\
$\quad$ Farm income/year & Million dong & 39.1 & 13.5 \\
$\quad$ Non-Farm income/year & Million dong & 8.1 & 21.9 \\
\hline \hline
\end{tabular}

Source: Survey results, 2019; 1 US $\$=23,000$ VND

\subsection{The current SLM practices in the Study area}

The current state of SLM adoption in Na Ri district is shown in Table 5. There are ten SLM practices adopted in farms in Na Ri district including agroforestry, manure use, crop rotation with legume, intercropping, seed improvement, lime, organic fertilizer, soil bunds, grass strips, terraces, among others, and fallow. Those practices were introduced through government programs and private sector firms such as extension training, media, and relatives. Although ten SLM practices are known in Na Ri district, adoption of SLM practices is low based on the household survey (Table 5). There were 109 households (54.5\% of respondents) that adopted SLM practices, while 91 households (45.5\% of respondents) did not adopt any SLM practice. Actually, one farmer can choose whatever practices he prefers to apply on his farm so that he can choose several practices at the same time or on the same plot. Therefore, one farmer could adopt a number of SLM practices which he/she felt suitable to the farming condition. The result shows that there were 32 households (16\%) adopting only one SLM practice, while there were 30 households (15\%) applying two practices. The number of respondents that adopted 3, 4 and 5 practices was 26 households (13\%), 17 households (8.5\%) and 4 households (2\%), respectively. 
Table 5. Adoption of sustainable land management practices, 200 farmer-respondents, Na Ri district, Bac Kan, 2019

\begin{tabular}{ccc}
\hline \hline Number of SLM Practices Adoption & Number Reporting & Percent (\%) \\
\hline 1 & 32 & 16.0 \\
2 & 30 & 15.0 \\
3 & 26 & 13.0 \\
4 & 17 & 8.5 \\
5 & 4 & 2.0 \\
6 & - & \\
7 & - & \\
8 & - & \\
\hline
\end{tabular}

Source: Survey results, 2019

From the total ten SLM practices adopted in Na Ri district by farmers, there were three commonly applied SLM practices. These are agroforestry, crop rotation with legume and manure use (Table 6). The major SLM practice observed agroforestry that was adopted by 94 farmers. Crop rotation with legume practice was adopted by 75 farmers. The use of manure was adopted by 61 farmers. The decision to adopt SLM practices depends upon a wide variety of factors. In this study, the determinants including risk preferences of the common SLM practices adoption decision were investigated.

Table 6. Common sustainable land management practices adopted, 200 farmerrespondents, Na Ri district, Bac Kan, 2019

\begin{tabular}{lcc}
\hline \hline SLM Recommended Practices Adopted & Number Reporting & Percent (\%) \\
\hline Agroforestry & 94 & 47.0 \\
Crop rotation with legume & 75 & 37.5 \\
Manure use & 61 & 30.5 \\
Intercropping & 7 & 3.5 \\
Seed improvement & 2 & 1.0 \\
Lime & 9 & 4.5 \\
Organic fertilizers made by factory & 1 & 0.5 \\
Soil bunds and grass strips & 7 & 3.5 \\
Terraces, among others & 1 & 0.5 \\
Fallow & 1 & 0.5 \\
\hline \hline
\end{tabular}

Source: Survey results, 2019

The reasons why they do not adopt SLM practices are shown in 7. Farmers mentioned inadequate knowledge of SLM practices, occurrence of calamity, lack of labor and capital, pests, diseases, lower productivity, and volatility of input and output prices. There were 168 respondents $(84.0 \%)$ who said that they are not familiar with SLM practices. Another reason is the occurrence of calamities like floods and drought. There is heavy rainfall during rainy season from May to September. When farmers adopt any SLM practices, they have to invest more in 
capital and labor. The occurrence of calamity may increase the probability of loss in farming so this prevents SLM adoption. There were 166 respondents (83.0\%) who mentioned that they worry about calamities, while 162 respondents $(81.0 \%)$ said that inadequate capital constrain them from adopting SLM practices. The high interest rate prevents the farmers from accessing capital from the bank or other sources in Na Ri district. Labor shortage was reported by $80.5 \%$ of the respondents for low SLM adoption. Pest and diseases were mentioned by 158 farmers (76.0\%) as a barrier to SLM adoption. There were 156 respondents (78.0\%) who feared about loss in farm productivity. The volatility of market input and output prices is also a reason for low adoption of SLM practices and other innovations. There were 146 respondents (73.0\%) who were afraid of low output price and 133 respondents $(66.5 \%)$ who were afraid of higher input cost. The other reasons mentioned by 59 respondents (29.5\%) are that SLM may not be suitable for their land or they do not have any references in their commune to be confident to adopt those SLM practices.

Table 7. Reasons for not adopting of SLM practices, 200 farmer-respondents, Na Ri district, Bac Kan, 2019

\begin{tabular}{lcc}
\hline \hline Reason & $\begin{array}{c}\text { Number } \\
\text { Reporting }\end{array}$ & Percent (\%) \\
\hline Inadequate knowledge of SLM practices & 168 & 84.0 \\
Calamity: flood, drought & 166 & 83.0 \\
Lack of capital & 162 & 81.0 \\
Lack of labor & 161 & 80.5 \\
Fear loss due to pest, diseases & 158 & 76.0 \\
Fear loss in productivity & 156 & 78.0 \\
Risk of low price of output & 142 & 71.0 \\
Risk of higher input cost & 133 & 66.5 \\
$\quad$ Others & 59 & 29.5 \\
\hline \hline
\end{tabular}

Source: Survey results, 2019

In agricultural activities, farmers in $\mathrm{Na} \mathrm{Ri}$ district have to face so many risks and constraints that are shown in Table 8. Risks are classified into four groups: risks with high probability of occurrence; risk with low probability of occurrence, risk with high expected damage and risk with low expected damage. The risks that farmers may face in adopting sustainable management practices in $\mathrm{Na} \mathrm{Ri}$ district are pests, fungi diseases, labor and capital constraints, market, calamity, wild grass, fake inputs, and slow germination. The high probability of occurrence refers to the common risks such as wild grass (166 respondents), pest, and fungi disease (151 respondents); market (138 respondents); labor constraint (137 respondents); capital constraint (122 respondents); and occurrence of calamities (107 respondents). The low probability of occurrence risks such as fake/bad quality input (reported by 145 respondents) and slow germination of seeds (reported by 152 respondents). The risks are also categorized into two groups, namely, high expected damage risk including pest and fungi disease, capital constraint, market, calamities, and fake inputs; and low expected damage risks including labor constraint, 
wild grass and slow germination. These risks are the reasons that prevent the farmers from adopting those practices. Given the risks that affect the adoption of farmers of SLM practices, there is a need to study their risk preferences, specifically, whether or not they are willing to take or avoid risk and how farmers can reduce risk themselves.

Table 8. Risks in farming, 200 farmer-respondents, Na Ri district, Bac Kan, 2019

\begin{tabular}{lcc}
\hline \hline Risk & Number Reporting & Percent (\%) \\
\hline High probability of occurrence & 166 & 83.0 \\
Wild grass & 151 & 75.5 \\
Pest and fungi diseases & 138 & 69.0 \\
Market & 137 & 68.5 \\
Labor constraint & 122 & 61.0 \\
Capital constraint & 107 & 53.5 \\
Calamity & & \\
Low probability of occurrence & 152 & 76.0 \\
Slow germination of seeds & 145 & 72.5 \\
Fake/ bad quality inputs & & \\
High expected damage & 151 & 75.5 \\
Pest and fungi diseases & 145 & 72.5 \\
Fake/ bad quality inputs & 138 & 69.0 \\
Market & 122 & 61.0 \\
Capital constraint & 107 & 53.5 \\
Calamity & & \\
Low expected damage & 166 & 83.0 \\
Wild grass & 152 & 76.0 \\
Slowly germination & 137 & 68.5 \\
Labor constraint & & \\
\hline \hline
\end{tabular}

Source: Survey results, 2019

\subsection{Determinants of the Upland Farmers' Adoption Decision on Sustainable Land Management Practices in Na Ri district, Bac Kan Province}

Most features of the SLM adopter group are significantly different from the non-adopter group. The proxy risk preference as measured by the number of safe decision choice and relative risk aversion of upland farmer are significantly different between the adopter and non-adopter groups at $1 \%$ probability level. Farm experience, total annual crop area, total forest and perennial crop area, knowledge of SLM practices, membership in farm organization, and number of labors are also significantly different between the two groups at $1 \%$ probability level. However, household size and slope of farm land are not significantly different for the two groups. The differences in the mean characteristics between the two groups indicate that these factors may impact adoption of the SLM practices.

The findings from Table 9 indicate that the SLM adopter - farmer likely has 18.7 years of farming experience, $4,349.5 \mathrm{~m}^{2}$ of annual crop area, and 7,239.4 $\mathrm{m}^{2}$ of forest and perennial crop area, knowledge of 7.33 out of 10 SLM practices, and 2.98 labors; makes 5.84 safe choices; and 
has relative risk aversion coefficient of 0.26 , on average. However, the SLM non-adopter farmers more likely has 27.4 years of farming experience, $3,088.5 \mathrm{~m}^{2}$ of annual crop area, $2,773.6 \mathrm{~m}^{2}$ of forest and perennial crop area, knowledge of 5.82 out of 10 SLM practices, 2.36 labors, and risk-averse is with 7.66 safe choices and relative risk aversion coefficient of 0.64 , on average. The result shows that the SLM adopters likely to have less farming experience, larger farm size, more labor, and more SLM knowledge; better trained, member of farmers' organization, and is less risk-averse than the SLM non-adopters.

Table 9. Physical, institutional and other characteristics of SLM adopter and non-adopter groups, 200 farmer-respondents, Na Ri district, Bac Kan, 2019

\begin{tabular}{|c|c|c|c|c|}
\hline Item & Non-adopter & Adopter & Difference & p-Value \\
\hline Observations & 91 & 109 & & \\
\hline Farming experience & 27.4 & 18.7 & $8.7^{* * *}$ & 0.000 \\
\hline Total annual crop area & $3,088.5$ & $4,349.5$ & $1261^{* * * *}$ & 0.000 \\
\hline Total forest and perennial crop area & $2,773.6$ & $7,239.4$ & $4,465.8^{* * *}$ & 0.000 \\
\hline Knowledge of SLM & 5.82 & 7.33 & $1.51^{* * *}$ & 0.000 \\
\hline Training ${ }^{\mathrm{a}}$ & 0.22 & 0.35 & $0.13^{* *}$ & 0.046 \\
\hline Member of organization $^{a}$ & 0.57 & 0.89 & $0.32^{* * * *}$ & 0.000 \\
\hline Credit $^{\mathrm{a}}$ & 0.01 & 0.09 & $0.08^{* *}$ & 0.013 \\
\hline Household size & 4.27 & 4.23 & $0.04^{\mathrm{ns}}$ & 0.795 \\
\hline Labor & 2.36 & 2.98 & $0.62^{* * * *}$ & 0.000 \\
\hline Slope of land & 2.79 & 2.81 & $0.02^{\mathrm{ns}}$ & 0.798 \\
\hline Number of safe decision choices & 7.66 & 5.84 & $1.82^{* * * *}$ & 0.000 \\
\hline Relative risk aversion coefficient & 0.64 & 0.26 & $0.38^{* * *}$ & 0.000 \\
\hline
\end{tabular}

a : Chi-square test for non-parametric variables;

$* * *, * *, *$ denote significance at $1 \%, 5 \%$ and $10 \%$ probability, respectively; ns: non-significant

The factors affecting SLM adoption of farmers in Na Ri district were examined by the 2SLS or IV-Probit model. The first stage of this model was the regression of relative risk aversion of upland farmer as discussed above. The second stage of model is regression using a binary variable for adoption as dependent variable. An adopter is a farmer using at least one SLM practice (Adopter $=1$; Non Adopter $=0$ ). The explainatory variables are physical, institutional and other characteristics including risk preferences such as farming experience, total annual crop area, total forest and perennial crop area, knowledge of SLM practices, training, membership in a farmers' organization, access to credit, household size, number of labors, slope of farm land, and relative risk aversion coefficient. The results of the IV Probit regression model on the determinants of SLM adoption are presented in Table 10. The Wald test of the hypothesis that all regression coefficients in are jointly equal to zero were rejected in the equation at $1 \%$ since Wald Chi square $(11)=38.29$, Prob> Chi square $=0.000$. This means that the empirical probit model is highly significant in explaining the decision of sustainable land management practices adoption by farmers. 
Table 10. Estimated regression results on risk preferences, physical, institutional and other characteristics affecting SLM adoption, 200 farmer-respondents, Na Ri district, Bac Kan, 2019

\begin{tabular}{lrccc}
\hline \multirow{2}{*}{ Independent Variable } & \multicolumn{4}{c}{ 2SLS Probit Regression } \\
\cline { 2 - 5 } & \multicolumn{1}{c}{ Coef. } & Std. Error & z-Value & p-Value \\
\hline Relative risk aversion & $-12.0600^{* *}$ & 4.8867 & -2.47 & 0.014 \\
Farming experience & $-0.0431^{*}$ & 0.0245 & -1.75 & 0.079 \\
Total annual crop area & $0.0003^{* *}$ & 0.0002 & 2.11 & 0.035 \\
Total forest and perennial crop area & $0.0003^{* * *}$ & 0.0003 & 3.87 & 0.000 \\
Knowledge of SLM practices & $0.1534^{* *}$ & 0.0743 & 2.06 & 0.039 \\
Training & -0.3578 & 0.4643 & -0.77 & 0.441 \\
Member of organization & 0.3904 & 0.4181 & 0.93 & 0.350 \\
Access to credit & 1.2285 & 5.5270 & 0.22 & 0.824 \\
Household size & -0.1718 & 0.1495 & -1.15 & 0.251 \\
Labor & 0.2953 & 0.2312 & 0.55 & 0.202 \\
Slope of land & 0.2203 & 0.3987 & 1.22 & 0.581 \\
Log likelihood & -56.2744 & & & \\
Prob> Chi square & 0.000 & & & \\
Wald Chi square (11) & 38.29 & & & \\
Number of observations & 200 & & & \\
\hline \hline
\end{tabular}

$* * *, * * *$ denote significance at $1 \%, 5 \%$ and $10 \%$ probability, respectively; ns: non-significant

Note: Dependent variable (adoption of SLM practices) is binary ( $1=$ adopter, $0=$ otherwise)

Relative risk aversion is a function of non-farm income, farm income, sex, age, and education.

The results indicate that there is a negative relationship between relative risk aversion variable and SLM adoption. This finding is consistent with the studies of Teklewold and Köhlin (2011) and Wang et al. (2016). The risk-loving farmers are more likely to adopt SLM practices, while the risk-averse farmers are more likely not to adopt SLM practices. Adoption of SLM practices may involve uncertainty and risks. For instance, applying crop rotation with legume may lead to pest and diseases, use of manure could improve the soil condition but could take a long time, while setting a soil bund and terracing would entail high labor and cost. The results indicate that if farmers' relative risk aversion could change from being risk-averse to slightly risk-averse or any of risk-loving class, the probability of SLM adoption will increase. It was found that a high degree of risk aversion significantly decreases the probability of adopting SLM practices. This implies that reducing farmers' risk exposure could promote SLM practices adoption in the study area.

Similarly, the result shows that there was a negative relationship between farming experience and the probability of SLM adoption. This finding is different from what was expected that farming experience would have a positive effect on the probability of SLM adoption. It is possible that the farmers' bad experience in the past discourages him from 
adopting SLM practices. On the other hand, farming experience is highly correlated with age of farmers. This means that the older farmer with higher experience in farming would usually stick with his current practices. He may not want to change to the new technology which requires higher technical knowledge and investment. Furthermore, the older farmers in $\mathrm{Na} \mathrm{Ri}$ district are less educated that prevents them from obtaining the new technologies. This finding is inconsistent with the findings of Babalola and Olayemi (2013) and Zeweld et al. (2018) who showed that farm experience has a positive sign effect on SLM adoption.

The results also show that there exists a positive significant relationship between the probability of SLM practices adoption and total annual crop area, total forest and perennial crop area, and knowledge of SLM practices. Total annual crop area is significant at 5\% probability level. This means that the farmer with larger annual crop is more likely to adopt SLM practices, while the farmer with smaller annual crop area is less likely to adopt SLM practices. The total forest and perennial crop area, similarly, has a positive effect on the probability of SLM practices adoption at $1 \%$ significance level. The farmers with larger total forest and perennial crop area are more likely to adopt SLM practices. Therefore, farm size has positive effect on the probability of SLM adoption. It means that farmers with larger farm size are more likely to adopt SLM practices, while those with smaller farm size are less likely to adopt such practices. This positive relationship could be due to the ability of large-scale farmers to purchase inputs or use laborsaving technologies. The farmers who have big farm sizes can easily borrow money from bank or other sources which will enhance their investment in farming. In this study area, land is a good collateral for borrowing money. Moreover, bigger farms usually have preferential access to government subsidy and other programs. The results indicate that every 1,000 square meters increase in total annual crop area, the probability of SLM practices adoption increases by $2.9 \%$. Also, every 1,000 square meters increase in total forest and perennial crop area would increase the probability of SLM practices adoption by 3.2\%. This finding on the effect of farm size on SLM adoption is similar with the studies of Kirui and Mirzabaev (2015) and Thanh and Chinawat (2015).

Finally, the result shows that farmers would not adopt any unknown practices, thus, having knowledge of SLM practices has a positive impact on the probability of SLM practices adoption. This finding is in line with the studies of Meijer et al. (2014), Nkonya et al. (2016), Wang et al. (2016), Saguye (2017a,c) and Zeweld et al. (2018). The upland farmers who know more SLM practices are more likely to adopt these practices, while the upland farmers who have less knowledge are less likely to adopt SLM practices.

\section{Conclusions and Recommendations}

There are ten SLM practices are known in Na Ri district, However, adoption of SLM practices is low based on the household survey. Three commonly applied SLM practices are agroforestry, crop rotation with legume and manure use. Inadequate knowledge of SLM practices, occurrence of calamity, lack of labor and capital, pests, diseases, low productivity, volatility of input and output prices, and other practices not suitable for their land are the reasons for non-adoption of SLM practices based on the household survey. In addition, farmers in $\mathrm{Na} \mathrm{Ri}$ district have to face so many risks and constraints in agricultural activities. The results of IV Probit model indicated that the following factors: risk preferences, farming experience, total annual crop area, total forest and perennial crop area and knowledge of SLM practices affect 
SLM adoption decision. Moreover, the risk preference of farmers has a strong effect on SLM practices adoption. The important consideration is how to reduce risk to the upland farmers and how to make them less risk averse. The study suggest that increase SLM practices adoption through better training, increasing the cultivated farm land, farm clustering, encouraging farmers to join farmers' organization, introducing and subsidizing labor-saving technologies, making credit accessible, improving insurance market, and demonstration plots for SLM practices.

\section{References}

AGBOOLA, W.L, S.A. YUSUF, A.S. OYEKALE and K.K. SALMAN. 2015. Determinants of Land Management Practices among Food Crop Farmers in North Central Nigeria. Journal of Environment and Earth Science 5 (21): 36-44.

BABALOLA, D. A. and J.K. OLAYEMI. 2013. Determinants of Farmers' Preference for Sustainable Land Management Practices for Maize and Cassava Production in Ogun State, Nigeria. Fourth International Conference, September 22-25, Hammamet, Tunisia 160578, African Association of Agricultural Economists (AAAE). Available online at: http://ageconsearch.umn.edu/record/160578/files/Babalola\%20D.\%20A\%20and\%20Olaye mi\%20J.\%20K.pdf

BEZABIH, M. and M. SARR. 2013. Risk Preferences and Environmental Uncertainty: Implications for Crop Diversification Decisions in Ethiopia. Available online at: https://www.researchgate.net/profile/Kinfe.../Risk_aversion.../BE.pdf

BRAVO-URETA, B.E., D. SOLIS, H. COCCHI and R.E. QUIROGA. 2006. The Impact of Soil Conservation and Output Diversification on Farm Income in Central American Hillside. Farming. Agricultural Economics 35(1): 267-276.

DADZIE, S.K.N. and H.D. ACQUAH. 2012. Attitudes Toward Risk and Coping Responses: the Case of Food Crop Farmers at Agona Duakwa in Agona East District of Ghana. International Journal of Agriculture and Forestry 2(2): 29-37.

KASAYE, B. 2017. Farmers' Willingness to Pay for Improved Soil Conservation Practices in Kuyu Woreda, North Shoa Zone of Oromia, Ethiopia: Application of Contingent Valuation Method. Singaporean Journal of Business Economics, and management studies (SJBEM) 5 (12): 39-48.

KEIL, A. and T. NIELSEN. 2012. Accounting for Farmers' Risk Preferences in Investigating Land Allocation Decisions in Marginal Environments: A Test of Various Elicitation Measures in An Application from Vietnam.

Available online at:

https://www.researchgate.net/publication/254387386_Accounting_for_farmers'_risk_prefe rences_in_investigating_land_allocation_decisions_in_marginal_environments_a_test_of_ various_elicitation_measures_in_an_application_from_Vietnam. 
KIRUI, O.K. and A. MIRZABAEV. 2015. Drivers of Land Degradation and Adoption of Multiple Sustainable Land Management Practices in Eastern Africa.

Available online at:

https://ageconsearch.umn.edu/bitstream/212008/2/Kirui-

Drivers $\% 20$ of $\% 201$ and $\% 20$ degradation $\% 20$ and $\% 20$ adoption $\% 20$ of $\% 20$ multiple $\% 20$ sustai nable\%20land\%20management\%20practices-1021.pdf.

LIU, T., R.J. BRUINS and M.T. HEBERLING. 2018. Factors Influencing Farmers' Adoption of Best Management Practices: A Review and Synthesis. Available online at:

https://www.researchgate.net/publication/322989235_Factors_Influencing_Farmers'_Adop tion_of_Best_Management_Practices_A_Review_and_Synthesis

MAGLINAO, A.R. 2000. Indicators of Sustainable Land Management for Slopeland Farms. Available online at:

http://www.fftc.agnet.org/library.php?func=view\&id=20110728094801.

MAO, H., L. ZHOU, J. IFFT and R.Y. YING. 2018. Risk Preferences, Production Contracts and Technology Adoption by Broiler Farmers in China. Available online at: https://doi.org/10.1016/j.chieco.2018.10.014.

MEIJER, S.S., D. CATACUTAN, O.C. AJAYI, G.W. SILESHI and M. NIEUWENHUIS. 2014. The Role of Knowledge, Attitudes and Perceptions in the Uptake of Agricultural and Agroforestry Innovations among Smallholder Farmers in Sub-Saharan Africa.

Available online at: http://dx.doi.org/10.1080/14735903.2014.912493.

MENOZZI, D., M. FIORAVANZI and M. DONATI. 2015. Farmer's Motivation to Adopt Sustainable Agricultural Practices. Bio-based Applied Economics 4 (2): 125-147.

NABOTH, B. 2015. Farmers' Knowledge, Perceptions, and Socioeconomic Factors Inflencing Decision Making For Integrated Soil Fertility Management Practices in Masaka and Rakai Districts, Central Uganda.

Available online at: htts://lib.dr.iastate.edu/etd/15231

NKONYA, E., N. GERBER, P. BAUMGARTNER, J.V. BRAUN, A.D. PINTO, V. GRAW, E. KATO, J. KLOOS and T. WALTER. 2011. The Economics of Land Degradation: Toward An Integrated Global Assessment. Available online at: https://ssrn.com/abstract=1890668 or http://dx.doi.org/10.2139/ssrn.1890668

NKONYA, E., A. MIRZABAEV and J.V. BRAUN, editors. 2016. Economics of Land Degradation and Improvement - A Global Assessment for Sustainable Development. Available online at:

https://www.researchgate.net/publication/286219120_Economics_of_Land_Degradation_a nd_Improvement_-_A_Global_Assessment_for_Sustainable_Development. 
OGADA, M.J., W. NYANGENA and M. YESUF. 2010. Production Risk and Farm Technology Adoption in the Rainfed Semi-arid Lands of Kenya. African Journal of Agricultural and Resource Economics, African Association of Agricultural Economists 4(2): 1-16.

SAGUYE, T.S. 2017a. Determinants of Adoption of Sustainable Land Management (SLM) Practices among Smallholder Farmers' in Jeldu District,West Shewa Zone, Oromia Region, Ethiopia. Journal of Resources Development and Management 8 (5): 96-116.

SAGUYE, T.S. 2017b. An Empirical Analysis of Land Degradation Risk from Local Community Knowledge Perspective: The Case of Geze Gofa District, Southern Ethiopia. Journal of Culture, Society and Development 28: 48-64.

SAGUYE, T.S. 2017c. Determinants of Adoption of Sustainable Land Management (SLM) Practices among Smallholder Farmers' in Jeldu District, West Shewa Zone, Oromia Region, Ethiopia. Global journal of Science Frontier Research (H) 17 (1): 67-83.

SAINT-MACARY, C., A. KEIL, M. ZELLER, F. HEIDHUES and T.M.D. PHAM. 2010. Land Titling Policy and Soil Conservation in the Northern Uplands of Vietnam. Land Use Policy 27: 617-627.

SAMANDARI, A.M. 2017. Gender- Responsive Land Degradation Neutrality. Available online at: https://knowledge.unccd.int/sites/default/files/2018-06/3.\%20GenderResponsive\%2BLDN_A_M_Samandari.pdf

SEMGALAWE, Z.M. 1998. Household Adoption Behaviour and Agricultural Sustainability in the Northeastern Mountains of Tanzania: The Case of Soil Conservation in the North Pare and West Usambara Mountains. Available online at: http://edepot.wur.nl/165791.

SUTTON, P.C., S.J. ANDERSON, R. COSTANZA and I. KUBISZEWSKI. 2016. The Ecological Economics of Land Degradation: Impacts on Ecosystem Service Values. Ecological Economics 129: 182 -192.

TEKLEWOLD, H. and G. KöHLIN. 2011. Risk Preferences as Determinants of Soil Conservation Decisions in Ethiopia. Journal of Soil and Water Conservation 66 (2): 87-96.

TENGE, A. J., J. DE GRAAFF and J.P. HELLA. 2004. Social and Economic Factors Affecting the Adoption of Soil and Water Conservation in West Usambara Highlands, Tanzania. Land Degradation and Development 15: 99-114.

THANH, N. V. and Y. CHINAWAT. 2015. Banana Farmers' Adoption of Sustainable Agriculture Practices in the Vietnam Uplands: the Case of Quang Tri Province. Journal of Agriculture and Agricultural Science Procedia 5: 67 - 74.

TIEN, T.M, 2015. Country Report: Vietnam Soil Resources. Asian Soil Partnership Consultation Workshop on Sustainable Management and Protection of Soil Resources. Bangkok. Available online at: http://www.fao.org/fileadmin/user_upload/GSP/docs/asia_2015/Vietnam.pdf 
VO, H.T., D.C. NGUYEN, Y. TAKAHASHI, S.W. KOPP and M. YABE. 2018. Modelling the Factors Affecting the Adoption of Eco-friendly Rice Production in the Vietnamese Mekong Delta. Cogent Food \& Agriculture 4: 1-24.

WEZEL, A., N. STEINMULLER and J.R. FRIEDRICHSEN. 2002. Slope Position Effects on Soil Fertility and Crop Productivity and Implications for Soil Conservation in Upland Northwest Vietnam. Agriculture, Ecosystems and Environment 91: 113-126.

WANG, N., Y. GAO, Y. WANG and X. LI. 2016. Adoption of Ecofriendly Soil-Management Practices by Smallholder Farmers in Shandong Province of China, Soil Science and Plant Nutrition 62 (2): 185-193.

WANG, Y., Y. ZHU, S. ZHANG and Y. WANG. 2018. What Could Promote Farmers to Replace Chemical Fertilizers with Organic Fertilizers? Journal of Cleaner Production 199: 882-890.

ZEWELD, W., G.V. HUYLENBROECK, G. TESFAY, H. AZADI and S. SPEELMAN. 2018. Impacts of Socio-Psychological Factors on Actual Adoption of Sustainable Land Management Practices in Dryland and Water Stressed Areas. Sustainability 10 (2963): 123. 